\title{
EVALUATING TENANTS' SATISFACTION WITH PUBLIC HOUSING IN LAGOS, NIGERIA
}

\author{
Adesoji David Jiboye \\ Department of Architecture, Faculty of Environmental Design and Management, \\ Obafemi Awolowo University, Ile-Ife, Nigeria \\ E-mail:adconsul@yahoo.com
}

Submitted 02 March 2009

\begin{abstract}
This paper examines tenants' satisfaction with public housing in Lagos, Nigeria. This was accomplished by assessing the levels of housing satisfaction of the general population and the degrees of satisfaction of tenants living in selected public housing estates within Lagos metropolis. Three (3) major housing components - environment (E), dwelling (D), and management (M), were identified and employed for this study. Six (6), representing $10 \%$ of estates, were randomly selected from forty (40) public housing estates in Lagos. Subsequently, questionnaires were administered to 1.022 (10\%), of households from the total of 12.323 households in the selected estates of the study area.

The data obtained from the survey were analyzed in two stages. First, is the use of descriptive analysis such as frequency tabulation to assess the general levels of tenants' housing satisfaction, and second, is the use of Satisfaction Indices (RSI) to determine the degree of tenants' satisfaction with each of the housing components identified for the study. The results of the analysis indicate that the level of tenants' housing satisfaction varies and is dependent on the environment, dwelling and management interaction systems. It demonstrated that the level of tenants' satisfaction with the housing environment and dwellings was above average (adequately satisfactory), but their level of satisfaction with the housing management was below average (unsatisfactory).

The study shows that users' inputs and preferences should be strongly considered by planners and public housing agencies when planning and designing public housing projects.
\end{abstract}

Keywords: Nigeria, tenants, public housing, satisfaction.

\section{Introduction}

Housing is one of the three basic needs of mankind. After the provision of food, it is the most important factor for the physical survival of man. It has been shown that housing is one of the best indicators of a person's standard of living and place in the society. Adeniyi (1974) observed that the availability of adequate housing, either in single or multiple units, is a significant component of the physical form and structure of a community. The family contents of the house denote the level of living standards and the degree of prosperity in the society. Therefore, housing is not limited to serving as a shelter alone. It is a space within which generations of families express their lifestyle, and preserve their history and identities of lineage (Awotona et al. 1994; Jiboye 2004).

There has been a general assumption that the physical and structural adequacy of a dwelling alone is a good measure of its suitability in providing satisfactory housing to its occupants. This generalization is nevertheless not enough to explain what is considered as satisfactory or adequate housing. Onibokun (1973) and Oladapo (2006) have observed that a dwelling that is adequate from the engineering or design point of view may not be adequate or satisfactory from the tenants' point of view. Therefore, the concept of an ideal home takes into account not only the physical, architectural 
and engineering components of the home but also the social, behavioral, cultural and personal characteristics of the inhabitants and the arrangements under which the dwelling is managed.

One of the tasks confronting policy-makers, planners, housing developers, and all those concerned with housing delivery is how to identify relevant factors or parameters which determine tenants' satisfaction with their housing and how to use this information in housing planning and development.

It is for this reason that this study becomes highly significant for the development of public housing in Lagos, Nigeria. The study focuses on the following objectives: assessment of the levels of tenants' satisfaction with public housing in the study area; and the evaluation of tenants' satisfaction with their housing.

The finding of this study is thus intended to provide a basis for the improvement of the quality of public housing in Nigeria.

\section{Theoretical issues}

The issues involved in housing for, the people are more than shelter. Kicklighter (1986) has observed that the concept of adequate housing implies more than just a dwelling, but includes all that is within the dwelling and the creation of a conducive environment in which people live and grow. Bauer (1951) has also observed that a dwelling that is adequate from the engineering or design point of view may not necessarily be adequate or satisfactory from the inhabitant's point of view. The house is only one link in a chain of factors which determine people's overall satisfaction level. Therefore, what constitutes housing satisfaction varies according to numerous related circumstances. Olayiwola (1997) noted that the satisfaction of tenants at a particular point in time can be meaningfully defined as being relative rather than absolute. It is not a matter of tenants being completely satisfied or dissatisfied. In other words, the housing satisfaction level of tenants varies and is dependent on dwelling, environment and management interaction systems.

Assessing the level of tenant's satisfaction would therefore require evaluating a particular housing unit located within a particular environment that is managed under a certain type of institutional management or administration (Onibokun 1974; Oladapo 2006).

Nevertheless, studies of human perception and behavior have shown that the interaction and interdependence of the components of a subsystem act as a stimulus to an individual in forming a cognitive ima- ge or mental picture of oneself and each of the other interacting components. Such an image becomes the basis of one's attitude and feelings towards each of the components of the system, and the totality of these feelings is the basis on which one's relative satisfaction with each subsystem depends (Lynch 1960).

The use of this information on housing has been negligible in most third world countries such as Nigeria. Therefore, it should be the purpose of research to identify various concepts contributing to satisfactory and acceptable housing. This would provide all stakeholders in housing development with valuable data on which an ideal tenant-dwelling-environment- management interaction could be based.

\section{The study area}

Lagos is located on the south-western coast of Nigeria (Fig. 1), between latitude $6^{0}$ and $7^{0}$ north of the equator, and longitude $3^{\circ}$ and $4^{0}$ east of the Greenwich Meridian. The city has a total area of 1,090 square kilometers where about 208 square kilometers are covered with water and mangrove swamps (UNCHS 2001). Lagos became the first federal capital following the attainment of Nigeria's independence in 1960. The metropolitan area is an urban complex consisting of millions of people from different ethnic, socio-cultural and economic backgrounds.

Since the shift of administrative seat to Abuja, Lagos has remained the major seaport and commercial nerve center of Nigeria, attracting migrants from all over the regions and nations of the world, and has witnessed considerable expansion (both spatially and demographically) over the years. Up to the end of the 18 th century, Lagos had a population of about 5,000 people. However, the city witnessed population explosion during the colonial period (Mabogunje 1968). The current official population figure released by the national population commission of Nigeria is 9 million (NPC 2006).

Official intervention in housing provision in Nigeria began when the Lagos Executive Development Board (LEDB) was created in 1928 to tackle the housingrelated bubonic plague at the time. This was done to get rid of the filth as well as the unhealthy living and housing condition that existed in Lagos. Since then the government's direct involvement in housing development and delivery has been on the increase. In 1972, the Lagos Executive Development Board (LEDB), metamorphosed into what is now known as the Lagos State Development and Property Corporation (LSDPC). 
Since its inception, it has been entrusted with the execution of several housing programs to cater for different populations of Nigerians (Diogun 1989; Mbali and Okoli 2002).

As a part of its efforts to reduce the problem of housing shortage in Lagos, the Federal Government also embarked on housing development for different populations of Nigerians residing within the Lagos Metropolitan Area. However, the direct impact of the Federal Government was not felt in housing provision for the masses in Lagos until 1973 when it established the Federal Housing Authority (F.H.A.). This was subsequently followed by the creation of the Federal Ministry of Housing, Urban Development and Environment (UNCHS 2001).

Today, public housing schemes developed by both the Federal and State governments exist in virtually every major location within the Lagos Metropolis. However, due to neglect and inadequate maintenance, most of these housing schemes are in a state of disrepair (Fig. 2).

\section{Method of data collection}

Primary data for this study were obtained by administering prepared questionnaires to selected households within the study area. Information on respondents' perception of levels of housing satisfaction was obtained from the selected public housing estates in Lagos (Table 1).

Using the questionnaires, six (6) housing estates representing one tenth $(1 / 10)$ of the total housing estates were randomly selected. Subsequently, 1,022 housing units or households representing ten percent of the total units were systematically sampled from the selected housing estates. The respondents to the questionnaire administration were the household heads. One household head per house was engaged in the interview and questionnaire administration. The data collected were analyzed using descriptive statistical analysis (such as frequency tables) and the evaluation of relative satisfaction indices (RSI). (See Anantharajan 1983).

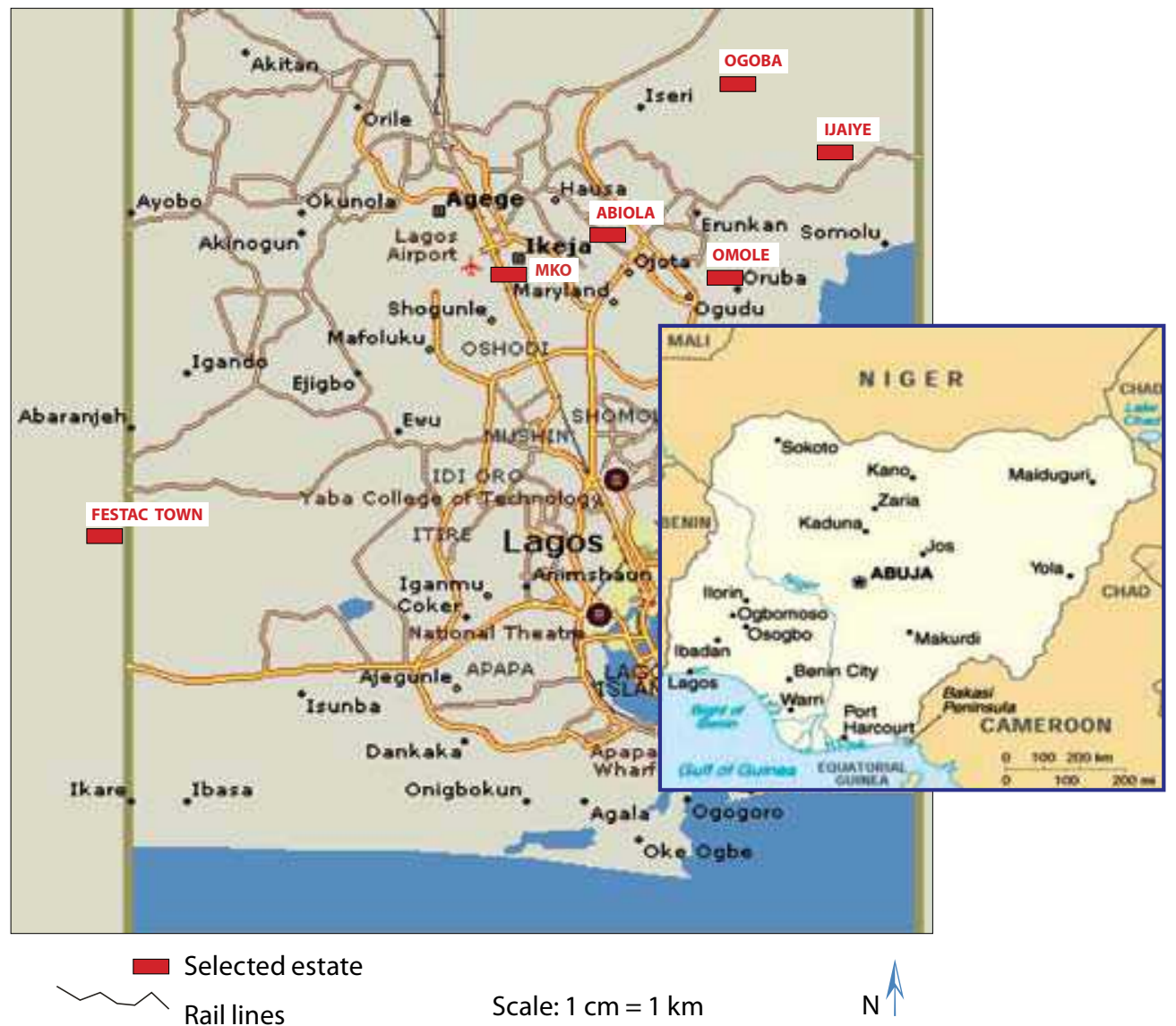

Fig. 1. Location of selected public housing estates in Lagos, Nigeria 

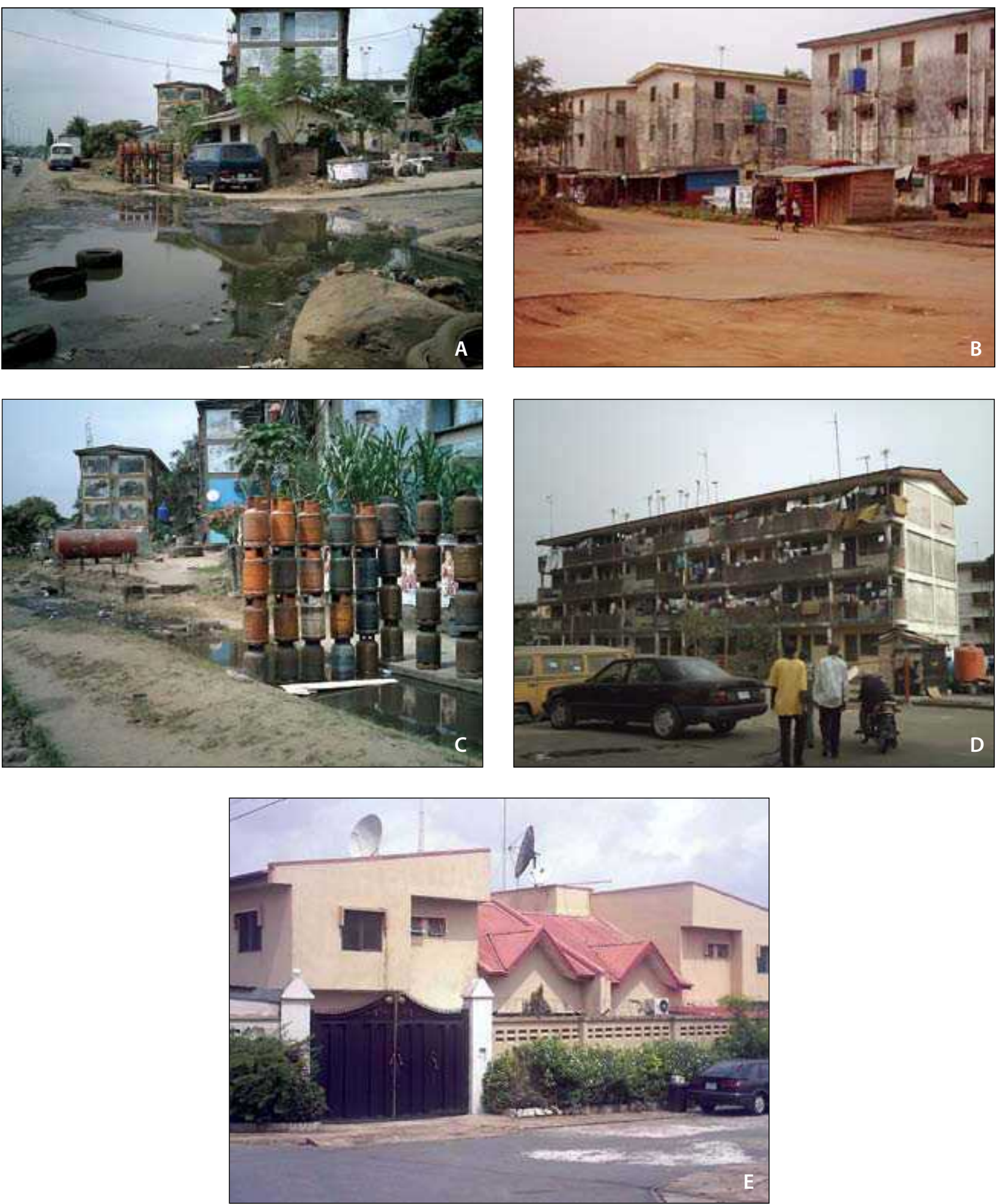

Fig. 2. Existing conditions of selected public housing estates in Lagos Metropolis: A - Deplorable road and neighborhood environment a major road flooded and littered with used tyres, B - Defaced buildings and housing environment occupied by makeshift (kiosk) extension for commercial purposes, C - Deplorable environment, and waterlogged drains. Domestic fuel tank and gas cylinders displayed within the neighborhood, D - Misuse of building balconies used for sun-drying clothes, and indiscriminate vehicular parking in open spaces, E-A typical well-maintained high-class public housing estate 


\section{Data analysis and discussion}

A review of available literature suggests that certain variables or parameters are relevant for public housing evaluation. Users' housing satisfaction was examined based on the interacting variables or factors of the dwelling (D), the environment (E), and the management (M) components of public housing (Table 2). Tenants' (respondents) satisfaction levels with these variables were obtained using a five-point Likert scale ranging from very dissatisfied (rated as 1 ) to very satisfied (rated as 5).

Subsequently, the total weight values (TWV) and the mean values $(\mathrm{X})$ for each variable or factor were obtained and used to evaluate the degree of housing satisfaction (RSI) for the tenants in the study area. The level of satisfaction being tested was determined by adopting the mid-point value of the index, which is three (3) (that is, average or fairly satisfactory), as the acceptable mean (Coakes and Steed 2001, cited in Oladapo 2006). This implies that any result significantly different from this mean value was assumed to be either positive or negative (Pulling and Haidar 2003, also cited in Oladapo 2006).

\subsection{Perception of housing satisfaction}

Table 3 shows the result of respondents' (tenants) rating levels of their satisfaction with housing in the study area. It is evident from Tables $3 a$ and $3 b$, that most respondents in the study area were generally satisfied with their housing environments. This is because the majority (42.3\% and 34\%); and (30.3\% and 9.5\%) of the respondents in the entire sample claimed that they were satisfied or very satisfied with their housing estate environment, in terms of the estate amenities and facilities (SEFA) as well as the overall estate appearance (SOHEE), respectively. About $20.7 \%$ and $54.4 \%$ of the respondents claimed they were minimally satisfied. Only a fragment of the entire sample $(2.5 \%$ and $0.5 \%)$; and (4.2\% and $1.6 \%$ ) indicated that they were dissatisfied or very dissatisfied with their estates environment.

Table 1. Housing samples for questionnaire administration

\begin{tabular}{ccccccc}
\hline S/No & $\begin{array}{c}\text { Category } \\
\text { of housing } \\
\text { estates }\end{array}$ & $\begin{array}{c}\text { Total no. of } \\
\text { estates }\end{array}$ & $\begin{array}{c}\text { No. of selected } \\
\text { estates }\end{array}$ & $\begin{array}{c}\text { Total no. } \\
\text { of housing units }\end{array}$ & $\begin{array}{c}\text { No. of selected } \\
\text { housing } \\
\text { units/households }\end{array}$ & $\begin{array}{c}\text { Copies } \\
\text { of retrieved } \\
\text { questionnaire }\end{array}$ \\
\hline $\mathrm{i}$ & Low Income & 23 & 3 & 11,077 & 1,108 & 897 \\
\hline $\mathrm{ii}$ & Medium Income & 11 & 2 & 896 & 90 & 90 \\
\hline $\mathrm{iii}$ & High Income & 6 & 1 & 350 & 35 & 35 \\
\hline & Total & 40 & 6 & 12,323 & 1,232 & 1,022 \\
\hline
\end{tabular}

Source: Author's field survey, 2008

Table 2. Variables of housing satisfaction in the study area

\begin{tabular}{l}
\hline Environment component (E) \\
Satisfaction with Estate Facilities and Amenities (SEFA) \\
Satisfaction with overall appearance of housing estate environment (SOHEE) \\
\hline Dwelling component (D) \\
Satisfaction with dwelling spaces (SAWDS) \\
Satisfaction with dwelling interior design (SAWDID) \\
Satisfaction with overall appearance of dwelling (SAWOD) \\
Satisfaction with dwelling ventilation (SAWDV) \\
Satisfaction with lighting in dwelling (SALID) \\
Satisfaction with privacy in dwelling (SAWPID) \\
\hline Management component (M) \\
Satisfaction with management involvement and response rate (SAMIR) \\
Satisfaction with management's attitude on rules and regulation (SAMAR) \\
Source: Author's field survey, 2008
\end{tabular}


Table 3. Respondents' (tenants') satisfaction level with housing

\begin{tabular}{llll}
\hline $\begin{array}{l}\text { Weight } \\
\text { value }\end{array}$ & Rating & Number $(n)$ & Percentage \\
$(W)$ & &
\end{tabular}

\begin{tabular}{|c|c|c|}
\hline $\begin{array}{l}\text { Weight } \\
\text { value }\end{array}$ & Rating & Number $(n)$ \\
\hline
\end{tabular}

$(w)$

(a) Satisfaction

with Estate Facilities and Amenities (SEFA)

\begin{tabular}{rlrr}
\hline 1 & Very dissatisfied & 5 & 0.5 \\
\hline 2 & Dissatisfied & 25 & 2.5 \\
\hline 3 & Just satisfied & 212 & 20.7 \\
\hline 4 & Satisfied & 432 & 42.3 \\
\hline 5 & Very satisfied & 348 & 34.1 \\
\hline & Total & 1,022 & 100 \\
\hline
\end{tabular}

(b) Satisfaction

with overall housing estate environment (SOHEE)

\begin{tabular}{rlrr}
\hline 1 & Very dissatisfied & 16 & 1.6 \\
\hline 2 & Dissatisfied & 43 & 4.2 \\
\hline 3 & Just satisfied & 556 & 54.4 \\
\hline 4 & Satisfied & 310 & 30.3 \\
\hline 5 & Very satisfied & 97 & 9.5 \\
\hline & Total & 1,022 & 100 \\
\hline
\end{tabular}

(c) Satisfaction

with dwelling spaces (SAWDS)

\begin{tabular}{rlrr}
\hline 1 & Very dissatisfied & 11 & 1.1 \\
\hline 2 & Dissatisfied & 100 & 9.8 \\
\hline 3 & Just satisfied & 298 & 29.2 \\
\hline 4 & Satisfied & 510 & 49.9 \\
\hline 5 & Very satisfied & 103 & 10.1 \\
\hline & Total & 1,022 & 100 \\
\hline
\end{tabular}

(d) Satisfaction

with dwelling interior design (SAWDID)

\begin{tabular}{rlrr}
\hline 1 & Very dissatisfied & 13 & 1.3 \\
\hline 2 & Dissatisfied & 24 & 2.4 \\
\hline 3 & Just satisfied & 393 & 38.5 \\
\hline 4 & Satisfied & 484 & 47.4 \\
\hline 5 & Very satisfied & 108 & 10.6 \\
\hline & Total & 1,022 & 100 \\
\hline
\end{tabular}

(e) Satisfaction

with overall dwelling (SAWOD)

\begin{tabular}{rlrr}
\hline 1 & Very dissatisfied & 22 & 2.2 \\
\hline 2 & Dissatisfied & 62 & 6.1 \\
\hline 3 & Just satisfied & 487 & 47.7 \\
\hline 4 & Satisfied & 376 & 36.8 \\
\hline 5 & Very satisfied & 45 & 7.3 \\
\hline & Total & 1,022 & 100 \\
\hline
\end{tabular}

(w)

(f) Satisfaction

with dwelling ventilation (SAWDV)

\begin{tabular}{rlrr}
\hline 1 & Very dissatisfied & 16 & 1.6 \\
\hline 2 & Dissatisfied & 49 & 4.8 \\
\hline 3 & Just satisfied & 258 & 25.3 \\
\hline 4 & Satisfied & 496 & 48.5 \\
\hline 5 & Very satisfied & 203 & 19.9 \\
\hline & Total & 1,022 & 100 \\
\hline
\end{tabular}

(g) Satisfaction

with lighting in dwelling (SALID)

\begin{tabular}{rlrr}
\hline 1 & Very dissatisfied & 32 & 3.1 \\
\hline 2 & Dissatisfied & 74 & 7.2 \\
\hline 3 & Just satisfied & 243 & 23.9 \\
\hline 4 & Satisfied & 549 & 52.7 \\
\hline 5 & Very satisfied & 134 & 13.1 \\
\hline & Total & 1,022 & 100 \\
\hline
\end{tabular}

(h) Satisfaction

with privacy in dwelling (SAWPID)

\begin{tabular}{rlrr}
\hline 1 & Very dissatisfied & 18 & 1.8 \\
\hline 2 & Dissatisfied & 28 & 2.7 \\
\hline 3 & Just satisfied & 209 & 20.5 \\
\hline 4 & Satisfied & 462 & 45.2 \\
\hline 5 & Very satisfied & 305 & 29.8 \\
\hline & Total & 1,022 & 100 \\
\hline
\end{tabular}

(i) Satisfaction

with management involvement and response rate (SAMIR)

\begin{tabular}{rlrr}
\hline 1 & Very dissatisfied & 97 & 9.5 \\
\hline 2 & Dissatisfied & 211 & 20.7 \\
\hline 3 & Just satisfied & 143 & 14.0 \\
\hline 4 & Satisfied & 140 & 13.7 \\
\hline 5 & Very satisfied & 46 & 4.5 \\
\hline- & no response & 385 & 37.7 \\
\hline & Total & 1,022 & 100 \\
\hline
\end{tabular}

\section{(j) Satisfaction}

with management's attitude on rules (SAMAR)

\begin{tabular}{rlrr}
\hline 1 & Very dissatisfied & 65 & 6.4 \\
\hline 2 & Dissatisfied & 342 & 33.5 \\
\hline 3 & Just satisfied & 278 & 27.2 \\
\hline 4 & Satisfied & 194 & 18.9 \\
\hline 5 & Very satisfied & 53 & 5.2 \\
\hline- & no response & 90 & 8.8 \\
\hline & Total & 1,022 & 100
\end{tabular}

Source: Author's field survey, 2008 
There is an apparent similarity between respondents' satisfaction with their dwellings (housing units) and the estate environment discussed above. A good number of the respondents interviewed claimed they were generally satisfied with their dwellings. The analysis shows that the majority of the respondents $\{(49.9 \%$ and $10 \%)$; (47.4\% and $10.6 \%)$; and $(36.8 \%$ and $7.3 \%)$, respectively\} claimed they were satisfied or very satisfied with their dwelling spaces (SAWDS), dwelling interior design (SAWDID) and the overall dwelling (SAWOD). Similarly, the majority $\{(48.5 \%$ and $19.9 \%) ;(52.7 \%$ and $13 \%)$; and (45.2\% and $29.8 \%)$, respectively $\}$ also claimed they were satisfied with the ventilation (SAWDV), lighting (SALID) and the level of privacy (SAWPID) in their dwellings. A good number of the respondents $\{(29.2 \%$ and $38.5 \%$; $47.7 \%$ and $25.3 \%$; and $23.9 \%$ and $20.5 \%$ ), respectively\} indicated that they were minimally satisfied with their dwellings (Table 3, c-h).

The analysis of the survey of respondents' satisfaction with the estate managements reveals a contrary result from those discussed above. Only a small proportion of the respondents (4.5\% and $13.7 \%$ ) and (5.2\% and $18.9 \%$ ) claimed they were very satisfied or satisfied. About $14 \%$ and $27.2 \%$ claimed they were minimally satisfied. Whereas a good number of the respondents (20.7\% and 9.5\%); and (33.5\% and 6.4\%), respectively, expressed dissatisfaction with the management in terms of their response and involvement in the estates' upkeep (SAMIR) as well as with their attitude towards enforcing rules and regulations and general conduct (SAMAR). (See Tables 3i and 3j).

This finding supports Ukoha and Beamish (1997) cited in Oladapo (2006), that the management dimension was a major source of dissatisfaction among public housing tenants in Nigeria.

\subsection{Evaluation of tenants' housing satisfaction.}

The analysis of respondents' (housing tenants') levels of satisfaction with housing was carried out using the values obtained from the rated variables of housing satisfaction discussed above to determine the indices for satisfaction.

Using the formula

$$
\operatorname{TWV}=(n) \times(w),
$$

where: TWV is the total weight values of rated variables; $n$ is no. of respondents; $w$ is weight of variables and the formula

$$
\text { R.S.I. }=\sum \overline{\mathrm{X}} /(n),
$$

where $\overline{\mathrm{X}}$ is the mean values of the rated variables, $n$ is no. of respondents.

Therefore,

$$
\text { R.S.I. }=\sum \overline{\mathrm{X}} /(N),
$$

where RSI is the relative satisfaction index, and $\sum \overline{\mathrm{X}}$ is the total sum of the mean of the rated variables; $N$ is no. of variables rated.

Using the equation stated above, the indices for housing satisfaction (RSI) were evaluated for all the variables of housing rated in Table 3 above. The results are presented in Table 4.

An examination of the result in Table 4a suggests that public housing tenants in the study area were generally satisfied with their estate environments. This is because the total weight value (TWVE) and the total mean score (XE) of all the variables rated in the sample are 7656 and 7.65, respectively, while the satisfaction index (RSIE) for the environmental component (E) is 3.82 .

These values imply that the tenants' level of satisfaction (RS) with their estate environment in the study area was above average (or adequately satisfactory) in the order of ranking. With regard to satisfaction with dwellings, it appears that most public housing tenants are satisfied with their dwellings. This claim is affirmed by the result in Table $4 \mathrm{~b}$, in which the total weight value (TWVD) and the total mean value (XD) of the dwelling variables are 22566 and 22.89 , while the satisfaction index (RSID) for the dwelling component (D) is 3.81 .

This result is similar to that discussed above which indicates that the tenants' level of satisfaction with their dwellings was above average (or adequately satisfactory) in the order of ranking. However, a contrary result is observed from the data on the level of satisfaction with the management of public housing. Tenants were generally dissatisfied with their housing managements. The result presented in Table $4 \mathrm{c}$ shows that the total weight value (TWVM) and the total mean value (XM) of the variables are 4362 and 5.55, respectively, while the satisfaction index (RSIM) is 2.77 . These values fall below the average (i.e. 3), therefore indicating a low satisfaction level in the order of ranking. The result implies that the tenants' level of satisfaction with their estate management was below average (or unsatisfactory).

This supports Ukoha and Beamish, cited in Oladapo (2006), that the management component was a major source of dissatisfaction among public housing tenants in Nigeria. The findings of this study also corroborated the findings by Onibokun (1973), Olayiwola (1997) and others, 
Table 4. Evaluation of tenants' housing satisfaction

\begin{tabular}{lcc}
\hline \multicolumn{2}{l}{ Variables of housing satisfaction } & \\
\hline (a) Environment variables $(\mathrm{E})$ & $\begin{array}{c}\text { Total weight values } \\
(\mathrm{TWV})\end{array}$ & $\begin{array}{c}\text { Mean values } \\
(\overline{\mathrm{X}})\end{array}$ \\
\hline Access to estate facilities and amenities & 4159 & 4.07 \\
\hline Overall estate environment & 3497 & 3.58 \\
\hline Total & 7656 & 7.65 \\
\hline $\mathrm{RSI}_{\mathrm{E}}=7.65 / 2=3.82$ & & \\
\hline
\end{tabular}

(b) Dwelling variables

\begin{tabular}{lcc}
\hline Adequacy of building spaces & 3664 & 3.69 \\
\hline Building interior design & 3716 & 3.74 \\
\hline Overall dwelling & 3486 & 3.49 \\
\hline Building ventilation & 3887 & 3.97 \\
\hline Lighting in dwelling & 3735 & 3.80 \\
\hline Privacy in dwelling & 4078 & 4.20 \\
\hline Total & 22566 & 22.89 \\
\hline $\mathrm{RSI}_{\mathrm{D}}=22.89 / 6=3.81$ & & \\
\hline
\end{tabular}

(c) Management variables $(\mathrm{M})$

\begin{tabular}{llc}
\hline $\begin{array}{l}\text { Managements' involvement in repairs } \\
\text { and administration/responsibilities }\end{array}$ & 1738 & 2.73 \\
\hline $\begin{array}{l}\text { Overall management attitude and ge- } \\
\text { neral conduct }\end{array}$ & 2624 & 2.82 \\
\hline Total & 4362 & 5.55 \\
\hline $\mathrm{RSI}_{\mathrm{M}}=5.55 / 2=2.77$ & & \\
\hline
\end{tabular}

Author's data, 2008

indicating that the level of tenants' satisfaction with housing varies and is dependent on the interaction between the dwelling, environment and management components or subsystems. This implies that tenants' satisfaction is relative rather than absolute in the assessment of public housing.

\section{Conclusions}

This paper has attempted to evaluate the levels of tenants' satisfaction with public housing in the Lagos Metropolis of Nigeria. In this regard, the study identifies the residents' satisfaction level within the dwelling, environment and management components of public housing.

The findings show that in the study area, the satisfaction level of tenants with their housing environment and dwellings is average, while the tenants' satisfaction level with the management is below average. The findings indicate that there are variations in the housing satisfaction levels of tenants, and these depend primarily on the dwelling, environment and management interaction subsystems. These findings thus suggest that while residents are satisfied with the dwelling and environment components, they find that the management component requires significant improvement.

The implications of these findings are that there is a need to investigate those salient features of housing, particularly within the context of the components which provide residents with the desirable level of satisfaction. Rather than employing the "package approach", a process by which the government provides housing to people without their participation in the decision-making, it is necessary that housing designs and development are integrated with the cultural context and social realities of the people.

This study points out that the need for adequate and satisfactory housing is crucial to the socio-economic, 
cultural and physical wellbeing of man. Therefore, this investigation can serve as an important document to housing agencies, architects, planners and developers alike in guiding them toward the application of appropriate design criteria and management requirements when planning future housing projects.

\section{References}

Adeniyi, E. O. 1974. The Provision of Housing. A Challenge to Urban Planning and Development in Africa. Wiser Publication. Lagos.

Anantharajan, T. 1983. Evaluation of Residential Development through Users' Ratings and Rankings of Environmental Attributes, in Ural, O. (Ed.). Proceedings of International. Association of Housing Science Congress on Housing. NW 7-12. Miami, Florida.

Awotona, A. and Ogunshakin, L. 1994. Multi-Habitation and Cultural Structures. Experiences from Nigeria. Book of Readings. Dept of Architecture O.A.U., Ile-Ife and CARDO Newcastle U. K.

Bauer, C. 1951. Social Questions in Housing and Community planning, Journal of Social Issues 7: 1-3.

Coakes, S. J.; Steed, L. G. 2001. SPSS: Analysis Without Anguish. John Wiley and Sons, Milton, UK.

Diogun, J. O. 1989. Housing Problems in Nigeria. LowIncome Housing Survey, Housing Today 6(1): 31-32.

Eldredge, H. W. 1967. "Housing and Community" in Taning Megalopolis. Anchor Books, 1. Edition 4.

Jiboye, A. D. 2004. An Assessment of the Influence of SocioCultural Factors on Housing Quality in Osogbo Nigeria. Unpublished M.Sc. Thesis. Department of Urban and Regional Planning, Obafemi Awolowo University, Ile-Ife, Nigeria.

Lynch, K. (Ed.). 1960. The Image of the City. Cambridge: The M. I. T. Press.

Mabogunje, A. L. 1968. Urban Landuse Problems in Nigeria. Institute of British Geographers. Special Edition No 1.

Mbali, I. and Okoli, O. G. 2002. Affordable Housing for Low-Income Group in Nigeria. A redefinition of the basic parameters, Housing Today 1(5): 16-17.

NPC. 2006. National Population Census of Nigeria. Federal Republic of Nigeria.

Oladapo, A. A. 2006. A Study of Tenant Maintenance Awareness, Responsibility and Satisfaction in Institutional Housing in Nigeria, International Journal of Strategic Property Management 10: 217-231.

Olayiwola, L. 1997. Environmental Quality in Nigeria: A Case Study of a University Living Quarters, Ife Planning Journal. 1(1): 71-76. Obafemi Awolowo University, Ile-Ife, Nigeria.

Onibokun, P. 1973. Environmental Issues in Housing Habitability, Environment and Planning, 5: 461-476. doi:10.1068/a050461

Onibokun, P. 1974. Evaluating consumers satisfaction with housing. An application of a System Approach, American Institute of Planners Journal 40(3): 189-200.
Pullin, L. and Haidar, A. 2003. Managerial values in local government - Victoria, Australia, The International Journal of Public Sector Management 16(4): 286-302. doi:10.1108/09513550310480042

Ukoha, O. M.; Beamish, J. O. 1997. Assessment of Resident and Public Housing in Abuja, Nigeria, Habitat international 21(4): 445-460. doi:10.1016/S0197-3975(97)00017-9

UNCHS. 2001. Nigeria National Trends in Housing Production Practices. Habitat Vol. 4. Internet document.

\section{GYVENTOJŲ PASITENKINIMO KOMUNALINIAIS BÜSTAIS LAGOSE (NIGERIJA) TYRIMAS}

\section{A. D. Jiboye}

Santrauka. Straipsnyje nagrinëjamas ir vertinamas Nigerijos miesto Lagos gyventojų pasitenkinimas municipalinio fondo būstais. Autoriaus tyrimas atskleidé, kad pats būstų ir jų aplinkos ívertinimas yra vidutinio lygmens, jų priežiūros ir tvarkymo lygis yra žemesnis. Nustatyta, kad gyventojų pasitenkinimą lemia ir socialinè bei ekonominè, kultūrinè ir fizinè gerovè. Autorius yra ịsitikinęs, kad jo tyrimo išvados ir rekomendacijos bus vertingos būstų statybos ir priežiūros istaigoms, planuotojams ir architektams, formuluojant naujus ateities būstų projektavimo ir priežiūros reikalavimus.

Reikšminiai žodžiai: komunalinis būstas, Lagosas, Nigerija, urbanistiné plètra, respondentai, gyventojai, federaliné ir municipalinè valdžia.

\section{ADESOJI DAVID JIBOYE}

Degrees: B.E.S, B. Arch. (Architecture and Design); M. Sc, Ph. D. (Urban and Regional Planning). Job position: lecturer. Job address: Department of Architecture, Faculty of Environmental Design and Management, Obafemi Awolowo University, Ile-Ife, Nigeria.E-mail:adconsul@yahoo.com, Telephone 2348032323637

Research interests: housing and urban development studies. 